\title{
The Impact of Biofuels on Food Prices; The Experiences of Brazil and United States
}

\author{
Ncube, Free. Pangani $1^{*}$, Ndlovu, Khuphukani Tshamu ${ }^{2}$, Tsegaye Asrat ${ }^{3}$ \\ ${ }^{1}$ Department of Economics, University of FortHare, Private Bag X1314 Alice, 5700, South Africa \\ ${ }^{2}$ Department of Development Studies, Institute of Development Studies (IDS-NUST), No. 21 Dunan Road, Byo \\ ${ }^{3}$ Department of Economics, University of FortHare, Private Bag X 9083, East London 5200, South Africa
}

\begin{abstract}
Using crops for fuel generates concerns over competition with food uses. In 2008 a global food crisis hit the world during a record-high commodity and energy prices that prompted hunger and political unrest in developing countries. This took place at the same time when biofuel production, reached its pinnacle in developed countries. This paper examines the effect that biofuel prices and or production has had on food prices in Brazil and United States (U.S.) by employing the panel cointegration and Dynamic Ordinary Least Squares (DOLS) method of analysis. In regressing food prices as a function of demand and supply factors, such as oil prices, biofuel prices, interest rates and biofuel production, the study found that the increase in biofuels production over the past eighteen years has had a significant impact on food prices. Over the period January 1995- December 2013, the study estimates that a one hundred percent increase in biofuels production across time and between countries results in the increase of food prices by $21,9 \%$. The study therefore rejects the null hypothesis that states, biofuel production does not have a statistically significant negative impact on food prices in U.S. and Brazil, and accepts the alternative that biofuel production does have a statistically significant negative impact on food prices in U.S. and Brazil. Other predictors of food prices that the study revealed as significant were oil and interest rates. Policy recommendations for other countries like South Africa are therefore, made based on the results obtained.
\end{abstract}

Keywords: Biofuels, U.S., Brazil, Food prices, Panel co-integration, DOLS.

\section{Introduction}

The transport sector consumes much of the energy in many countries. Rapidly growing fossil energy consumption in this sector in the last two decades has raised concerns over its contribution to greenhouse gas emissions, supply insecurity issues and growing energy dependency. Hence the oil crisis of the 1970s aggravated the need to take action. In a bid to try and deal with the crisis, the attention in biofuels as a substitute to fossil fuels for use in the transport sector became an option for many countries. However, the subsequent drop in oil prices that followed somehow mired the momentum of biofuel production in most of the countries especially developing countries, with the notable exclusion of Brazil. Brazil has since then 
grown its biofuel markets and today Brazil and United States have been recorded as the most successful when it comes to biofuel production (Liu, 2005). New issues have arisen that have again motivated the use of biofuels as an unconventional energy. One of these is the issue of climate change consciousness. Environmental bodies like Kyoto Protocol have been since their inception advocating for the reduction of greenhouse gas emissions. The Millennium Development goals (MDG7 precisely) also advocates for such environmental sustainability (Clark, 2003).Most developing countries as signatory to these environmental bodies and in their bid to achieve the MDGs, have therefore been motivated to take up biofuels as they are believed to have the ability to succour in climate change mitigation through displacing fossil fuel combustion that occurs when fossil fuels are burnt to release energy (U.S Department of Energy, 1999). In addition to climate consciousness, soaring oil prices, the need for a secure domestic energy source and opportunity for trade has also further prompted the use of biofuels. According to (Boddiger, 2007) the former Brazilian president LuizInacio Lula da Silva, was of the opinion that "the developed world's demand for biofuels presents a great opportunity for African, Asian, and Latin American countries to bridge the gap between rich and poor nations by producing more biofuel crops and exporting them". Lula (Brazilian president), assumes that increased commodity prices would result in extra money for the poor farmers. It seems most African countries agreed with this as it saw many countries including, Zimbabwe, Kenya, South Africa, Malawi and Mozambique initiate biofuel programmes.

The 2008 food crisis happened at the time when biofuel production was at its pinnacle, however this growth id prices is steadier but higher on average (Sihvonen, 2017).For example palm oil and wheat inflation price is $47 \%$ and $32 \%$ higher respectively in comparison to 2005 (Sihvonen, 2017). However, not all the increase can be blamed on biofuels they are other factors but biofuels is a significant contributor. In trying to unravel how this food crisis came to be, many articles and various international agencies have identified biofuels having played a role among other factors. The World Bank (2008, in (Sharma, 2008), postulate that, "needs of the increasing population, demand for biofuels, growing middle class in India and China with increasing purchasing power and erratic weather are among the reasons that have pushed food prices". A report by Actionaid in (Rice, 2009) further affirms that biofuels are conservatively projected to have been responsible for at least 30\% of the global food price spike in 2008. In September 2017 a food price briefing report by (Sihvonen, 2017) after an extensive review of literature on biofuels and food prices concluded that policies to promote food based biofuels do lead to food price increases.

From the above, one can conclude that there is some form of causality between biofuels and food prices. It has been suggested that the demand for biofuels causes its price to increase, as its price increases, the feedstock into the biofuel process (grains and oil food) also face an increase in prices (Alexander \& Hurt, 2007).Accordingly, higher need for energy crops likewise outcomes into rising prices of other crops that have to contend for similar land. Hence according to Alexander and Hurt (2007), "consumer food prices can eventually be expected to rise as these higher crop prices are passed through the food system". For instance, increase in wheat prices is quickly reflected in increase in flour price, then passed relatively slowly to the bakery and finally reflect in the price of bread.

\subsection{Statement of the Problem}

Most developing and emerging market countries just like U.S. are large oil consumers; however, since 2011 the BRIC countries have surpassed the United States (US) in oil consumption. Pettinger (2011) ascertains that in 1970, 2008 and 2010-11 food prices inflated due to cost-push inflation emanating from oil price increases. However higher oil prices directly not only affect the supply of food as transportation costs rise but also make biofuel production more profitable and hence exacerbate the demand for grains. This culminates to increase in food prices. However, biofuels (cheaper and cleaner) adopted as an alternative for oil, has the downside of also inflating food prices (Pettinger, 2011). A research project by Melinda and Gates Foundation (2012), revealed that biofuel expansion in the EU, US, and Brazil has had and will have a substantial effect on global food prices. "Compared with the reference, the world average export price of maize, soybean, other oilseeds, and sugar will rise by $17.7 \%, 13.6 \%, 27.6 \%$ and $11.3 \%$, respectively, in 2020 " 
Ncube et al. Adv. J Social Sci.; Vol. 2 Issue 1, pp: 12-22, May 2018

(Melinda and Gates Foundation, 2012). The same problem of food inflation exists also in Brazil as suggested by Stauffer and Silvio Cascione (2013) who claim "Brazil, an up-and-coming agricultural superpower with abundant fertile land, is struggling to provide consistently affordable food for its population" (Stauffer \& Cascione, 2013).

According to (Amadeo, 2017) for the past two decades food prices have rose by approximately $2.6 \%$ a year on average to date. The increasing food prices have not been an exception to the developing countries, the great concern being that the impacts can be large as the price of food staples can represent a third of the total household spending with food consumption being highly sensitive to food prices (Sihvonen, 2017). However, over the past decade, an increasing number of developing countries have adopted biofuels policies, some with targets and mandates for transport fuel blending. For example, South Africa it set their biofuel blending mandate on the $1^{\text {st }}$ of October 2015. It is therefore evident that a problem of food inflation is already gripping developing countries, and the question that arises is will biofuels not worsen food inflation in these developing countries? In this light, the study seeks to address this question by investigating the impact that biofuels have on food

\section{$1.2 \quad$ Literature Review}

(Fortenbery \& Park, 2008), studied the effect of biofuel production on the U.S. food prices. They make use of three-stage least squares "to estimate a system of equations representing corn supply, feed demand, export demand, food, alcohol and industrial (FAI) demand, and corn price. A price dependent reduced form equation is then modelled to examine the effect of ethanol production (proxy for biofuel production) on the national average corn price and sugar prices" (Fortenbery \& Park, 2008). Quarterly data for 11 years was used, spanning from the $2^{\text {nd }}$ quarter of 1995 (Dec 1995) to first quarter of 2006 (Nov 2006). They conclude that ethanol production is positively related to both food demand and corn prices. They also established that in equilibrium a positive relationship exists between the ethanol, sugar and oil prices. Briefly, they conclusion point out that biofuel production will increase food demand and prices of commodity prices causing food prices to increase.

In a U.S study, Qiu, Colson, Escalante, \& Wetzstein, (2012) employed a "structural vector auto regression (SVAR) model along with a direct acyclic graph to decompose how supply/demand structural shocks affect food and fuel markets". The results are consistent with Kappel et al. (2010) that fundamental market forces of demand and supply had been the contributors of the 2007-2008 food inflation crisis. Hence, their study concluded that the hypothesis of food price volatility being influenced by market forces could not be rejected. They conclude based upon SVAR estimation of monthly time series data from January 1994 to October 2010 that, " within the short run, increased biofuel production may cause food price increases however the same does not hold for long-run price shifts" (Qui, Colson, Escalante, \& Wetzstein, 2012). In the long run, the food versus fuel issue does not hold.

A study in Brazil by (Balcombe \& Rapsomanikis, 2008) made use of weekly data from July 2000 to May 2006. They used a Taylor series expansion of VECM and AVECM, and they found out that biofuel prices affected feedstock prices and consequently food prices. Also, (Serra, Zilberman, \& Gil, 2011) studied the volatility spillovers in Brazil's ethanol market. The authors used weekly international ethanol, sugar and crude oil prices from July 2000 to February 2008. They discovered that in equilibrium prices of ethanol are positively related to both the prices of oil and sugar.

Teweldemedhin and Mwewa used a case study based on Meta evaluations to assess biofuel production and its impact on food security in Zambia. They concluded that there is possible diversion of labour and land to bio-fuel and competition of input that led to reduction of food production and high food prices (Teweldemedhin \& Mwewa, 2013). Terungwa (2009) made use of the theory of unintended consequences to evaluate the impact of biofuels on food security in Nigeria. Terungwa (2009) tests the following hypothesis, "would production of fuel crops cause increases in prices of related food crops?" Making use of descriptive statistics, data (1979-2003) of the selected crops discovered that, "the production of biofuels would impact negatively on food production as fuel, food and industries compete for available crop stocks thereby 
increasing food prices" (Terungwa, 2009). Sihvonen (2017) made an analysis of over one hundred economic modelling studies of the potential of food price increases due to increased biofuel demand and over two dozen assessments of the role played by biofuels during the 2008 food crisis. He concludes policies that promote food based biofuels lead to an increase in prices. Most of the literature focussed on the 2008 food crisis this study intends to see the impact even after the 2008 food crisis.

\section{Materials and Methods}

This study employs a panel data analysis to examine the impacts of biofuels on food prices in U.S. and Brazil from 1995 to 2013.There are three types of data generally available for empirical analysis; these include time series, cross section, and panel. Panel data is more of the combination of the two above (timeseries and cross-sectional). Panel data has advantages over time series and cross sectional. Panel data gives extra informative data, less collinearity among variables and more efficiency. Because market shocks by quintessence tend to occur at high frequency, this study therefore made use of monthly data to circumvent this. Hence, 227 observations were employed, which involved monthly observations spanning from 1 st month in 1995 to last month in 2013 for food prices and its 4 regressors ethanol prices, oil prices, ethanol production and interest rates. The start and end date of the observed period was restricted to availability of price series of the biofuels, its production and presence of outliers in food price data. The Levin-Lin-Chu test, IM, Pesaran and Shin test and Fisher- ADF unit root tests for stationarity in the panel series was used whilst the Pedron test was used for panel cointegration. The study employed DOLS (Dynamic Ordinary Least Squares estimation) to determine the long run relationships among variables. Diagnostic checks like the JaqueBera were perfomed. Food prices are modelled as a function of its supply factors (oil prices and ethanol prices) and its demand factors (biofuel production, previous year food prices and interest rates). This is expressed as following:

$$
\mathrm{FP}_{\mathrm{it}}=\beta_{0}+\beta_{1} \mathrm{Poil}_{\mathrm{it}}+\beta_{2} \mathrm{BPr}_{\mathrm{it}}+\beta_{3} \mathrm{BP}_{\mathrm{it}}+\beta_{4} \mathrm{IR}_{\mathrm{it}}+\beta_{5} \mathrm{D}_{\mathrm{it}}+\varepsilon_{i}+u_{i t} \ldots \ldots \ldots \ldots \ldots \ldots \ldots \ldots \ldots \ldots \ldots \ldots \ldots \ldots \ldots \ldots \ldots \text { (i) }
$$

However, the estimated econometric model is the following logged equation

$$
l \mathrm{FP}_{\mathrm{it}}=\beta_{0}+\beta_{1} / \mathrm{Poil}_{\mathrm{it}}+\beta_{2} / \mathrm{BPr}_{\mathrm{it}}+\beta_{3} / \mathrm{BP}_{\mathrm{it}}+\beta_{4} / \mathrm{IR}_{\mathrm{it}}+\beta_{5} \mathrm{D}_{\mathrm{it}}+\varepsilon_{i}+u_{i t} \ldots \ldots \ldots \ldots \ldots \ldots \ldots \ldots \ldots \text { (ii) }
$$

Where:

IFP $=$ logof food prices. This study will use monthly CPI for food in Brazil and in U.S. as a proxy for food prices. The CPI is based on $2000=100$

Poil $=\log$ prices of crude oil. The study intends to use monthly prices of crude oil in Brazil and U.S. Crude oil like any other form of energy is an input into the production of agriculture commodities hence it will impact on the pricing of the food. The study uses U.S. dollars for crude oil prices.

$\mathbf{B P r}=$ monthly logged prices of bioethanol. Ethanol prices are a proxy for biofuel prices, seeing that both U.S. and Brazil produce more of ethanol and just a bit of biodiesel. Biodiesel data is limited since much of it within these two countries was mandated in the mid-21 ${ }^{\text {st }}$ century around 2005. Ethanol prices are given in U.S. dollars.

$\mathbf{I B P}=\log$ of biofuel production in Brazil and U.S. biofuel production in million-gallon litres is used for both countries.

$\boldsymbol{I} \mathbf{R}=\log$ interest rates. There are different types of interest rate; this study uses the repo rate of these two countries. The repo rate has advantages that altering the repo rate affects short-term liquidity in the monetary system, which quickly has an effect on all other rates, and these other rates like the mortgage will adjust in line with changes in the official rate. In addition, the repo rate can change monthly.

D. Dummy variable for rainfall, when there is a drought then $\mathrm{D}=(1)$ otherwise $\mathrm{D}=(0)$

$\boldsymbol{\mu}=$ an error term. It captures the influence of any explanatory variables possibly omitted in the model and any mistake in measurement of the dependent variable. istands for the $i$ th cross-sectional unit and $t$ for the th time period. 
Ncube et al. Adv. J Social Sci; Vol. 2 Issue 1, pp: 12-22, May 2018

To determine the long run relationships among variables we model the impact of food prices as:

$$
\begin{gathered}
l \mathrm{FP}_{\mathrm{it}}=\beta_{0}+\beta_{1} / \mathrm{Poil}_{\mathrm{it}}+\beta_{2} / \mathrm{BPr}_{\mathrm{it}}+\beta_{3} / \mathrm{BP}_{\mathrm{it}}+\beta_{4} / \mathrm{IR}_{\mathrm{it}}+\beta_{5} \mathrm{D}_{\mathrm{it}}+\ldots \ldots \sum_{s=-p}^{p} \beta_{\mathrm{s}} \Delta / \mathrm{BP} \mathrm{P}_{\mathrm{it}-\mathrm{s}}+\sum_{s=-p}^{p} \delta_{\mathrm{s}} \Delta / \mathrm{IR}_{\mathrm{it}-} \\
{ }_{\mathrm{s}}+\sum_{s=-p}^{p} \chi_{\mathrm{s}} \Delta / \mathrm{BPr}_{\mathrm{it}-\mathrm{s}}+\sum_{s=-p}^{p} \varphi_{\mathrm{s}} \Delta / \mathrm{Poil}_{\mathrm{it}-\mathrm{s}}+\sum_{s=-p}^{p} \alpha_{\mathrm{s}} \Delta \mathrm{D}_{\mathrm{it} \mathrm{s}}+u_{i t} \ldots \ldots \ldots \ldots \ldots \text { (iii) }
\end{gathered}
$$

$\ldots \mathrm{s}, \mathrm{m}$, and $\mathrm{p}$ are the lag lengths of leads and lags.

Given that Food Prices (FP) are found to be integrated of order one I(1) and at least some of the right had side (RHS) variables I(1) or I(0), then DOLS estimates are obtained by the regression equation (iii) which is the extended version of a Dynamic OLS (DOLS) model.

\section{Results and Discussion}

\subsection{Unit Root/Stationarity Test Results}

Therefore, an informally graphical analysis is conducted and presented below in Figure 1. Figure 1 shows data in levels and Figure 2 first differenced data. To ascertain if time series data contains no unit root, one checks if the plots on a graph are oscillating around the zero mean. Figure 1 shows that plots of food prices, interest rates, oil prices, ethanol prices, bioethanol production, food prices lagged by one period and food prices lagged by two periods does not oscillate around a certain zero mean. Hence, the series in levels is clearly non-stationary. Differencing ensures that economic data is stationary in order to circumvent for spurious regressions. Data that Figure 2 shows variables are integrated of the first order I (1) as they oscillate around the zero mean. This implies that the data becomes stationary after first differencing.

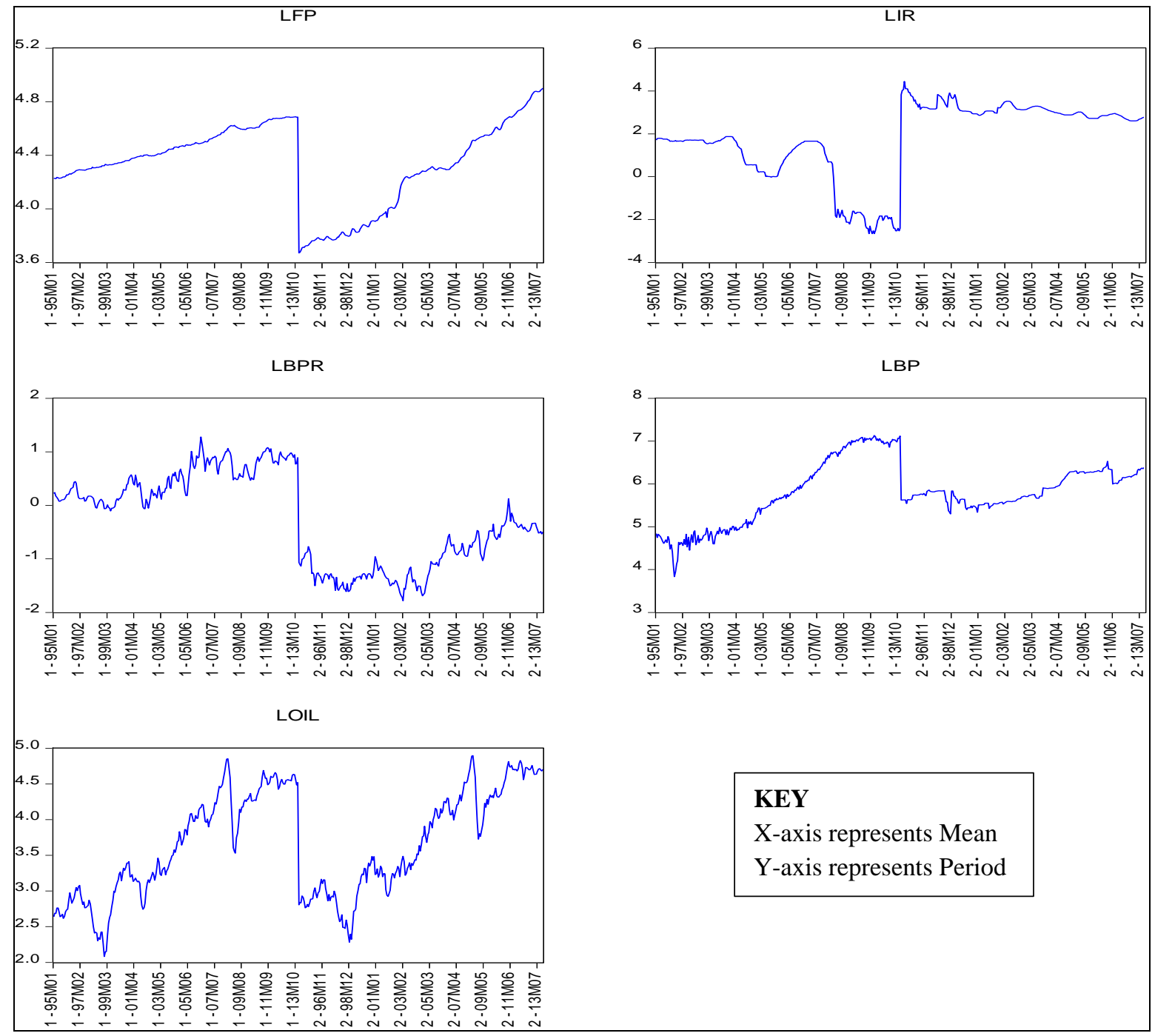

Figure 1: Plots of variables at level 


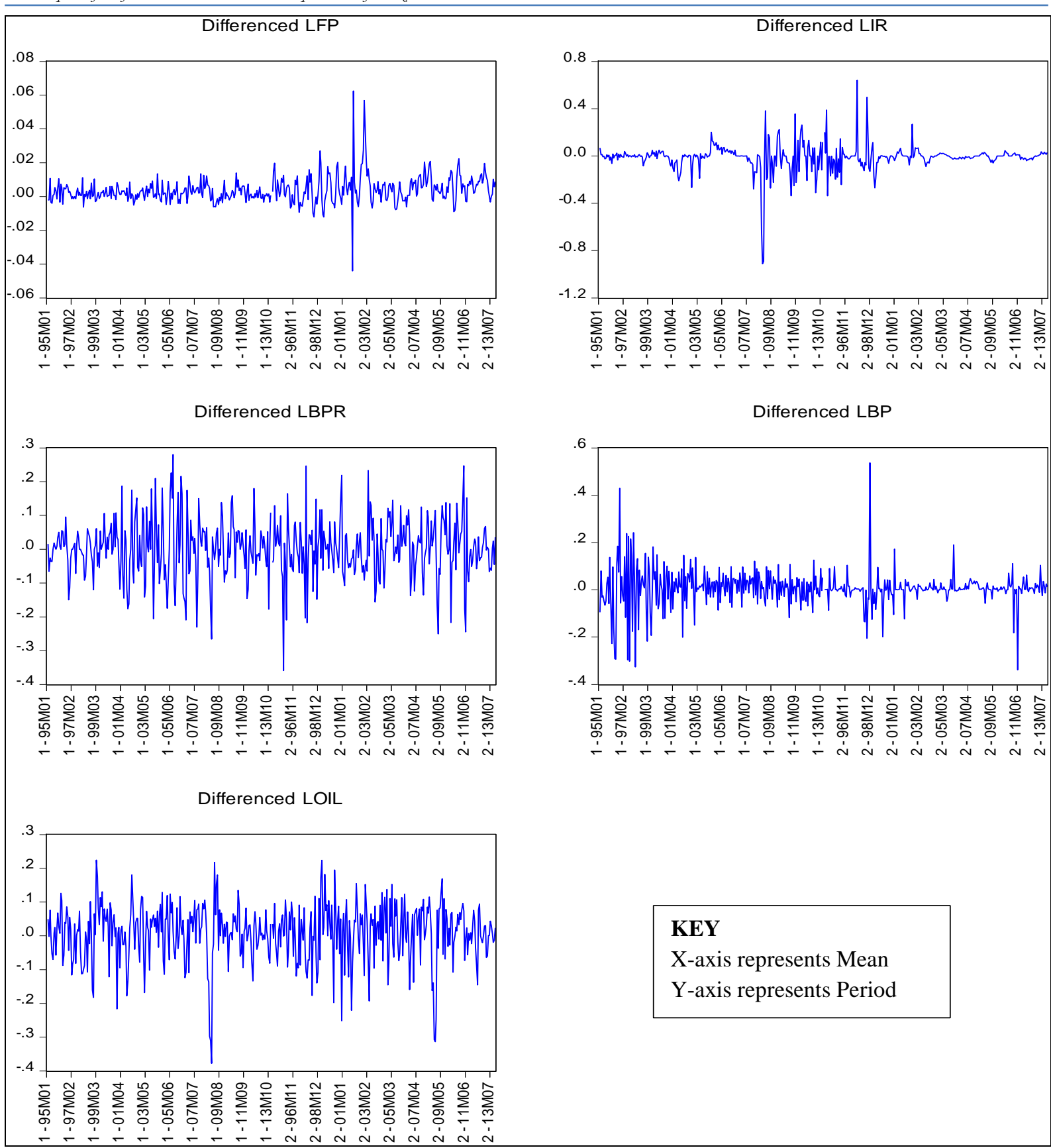

Figure 2: Plots of first differenced variables

In order to test for the incidence of unit roots and the alternative to that in the panel data series contained within this study, recent panel unit root tests including Levin, Lin and Chu (LLC), Im, Pesaran and Shin (IPS), Fisher-ADF and Fisher PP tests are conducted. Table 1 presents the results of four panel unit root tests. The tests were conducted to test variables in (a) intercepts and (b) trends and intercepts.

All the four tests reveal that at level whether in trend or in trend and intercept the variables are nonstationary. For first differences of all the series, it shows that these are stationary. Hence, all the variables are integrated of order one $[I(1)]$ and all the four tests indicate that all variables become stationary after first differencing. These results are consistent with the informal tests carried out which also revealed graphically that the variables only become stationery after first differencing. 
Ncube et al. Adv. J Social Sci.; Vol. 2 Issue 1, pp: 12-22, May 2018

Table 1: Stationarity tests results in levels and first differences

\begin{tabular}{|c|c|c|c|c|c|c|c|c|c|}
\hline \multicolumn{5}{|c|}{ Trend statistics with intercept } & \multicolumn{4}{|c|}{ Trend statistics with intercept and trend } & \multirow{2}{*}{$\begin{array}{l}\text { Order of } \\
\text { integration }\end{array}$} \\
\hline Variable & LLC & IPS & $\mathrm{ADF}$ & PP & LLC & IPS & $\mathrm{ADF}$ & PP & \\
\hline$l$ FP & $\begin{array}{l}3.516 \\
(\mathbf{0 . 9 9 9 )}\end{array}$ & $\begin{array}{l}4.6671 \\
(\mathbf{1 . 0 0 0 )}\end{array}$ & $\begin{array}{l}0.1213 \\
(\mathbf{0 . 1 0})\end{array}$ & $\begin{array}{l}0.0700 \\
(\mathbf{0 . 1 0})\end{array}$ & $\begin{array}{l}0.9839 \\
(\mathbf{0 . 8 3 7})\end{array}$ & $\begin{array}{l}0.2921 \\
(\mathbf{0 . 6 1 5})\end{array}$ & $\begin{array}{l}1.0721 \\
(\mathbf{0 . 8 5 8 )}\end{array}$ & $\begin{array}{l}2.7621 \\
(\mathbf{0 . 5 9 8 )}\end{array}$ & $\mathrm{I}(1)$ \\
\hline DlFP & $\begin{array}{l}-5.899 \\
(\mathbf{0 . 0 0}) *\end{array}$ & $\begin{array}{l}-5.660 \\
(\mathbf{0 . 0 0}) *\end{array}$ & $\begin{array}{l}41.569 \\
(\mathbf{0 . 0 0}) *\end{array}$ & $\begin{array}{l}161.27 \\
(\mathbf{0 . 0 0}) *\end{array}$ & $\begin{array}{l}-7.728 \\
(\mathbf{0 . 0 0}) *\end{array}$ & $\begin{array}{l}-5.890 \\
(\mathbf{0 . 0 0})^{*}\end{array}$ & $\begin{array}{l}41.135 \\
(\mathbf{0 . 0 0}) *\end{array}$ & $\begin{array}{l}162.04 \\
(\mathbf{0 . 0 0}) *\end{array}$ & $\mathrm{I}(0)$ \\
\hline lI.R. & $\begin{array}{l}-0.7996 \\
(\mathbf{0 . 2 1 2})\end{array}$ & $\begin{array}{l}-2.097 \\
(\mathbf{0 . 0 2}) *\end{array}$ & $\begin{array}{l}13.970 \\
(\mathbf{0 . 0 1}) *\end{array}$ & $\begin{array}{l}7.0969 \\
(\mathbf{0 . 1 3 0})\end{array}$ & $\begin{array}{l}-0.734 \\
(\mathbf{0 . 2 3 1 )}\end{array}$ & $\begin{array}{l}-2.478 \\
(\mathbf{0 . 0 1}) *\end{array}$ & $\begin{array}{l}14.861 \\
(\mathbf{0 . 0 6}) *\end{array}$ & $\begin{array}{l}9.1264 \\
(\mathbf{0 . 0 6}) *\end{array}$ & $\mathrm{I}(1)$ \\
\hline DlI.R & $\begin{array}{l}-1.4941 \\
(\mathbf{0 . 0 6 8 )}\end{array}$ & $\begin{array}{l}-5.699 \\
(\mathbf{0 . 0 0}) *\end{array}$ & $\begin{array}{l}42.691 \\
(\mathbf{0 . 0 0}) *\end{array}$ & $\begin{array}{l}165.93 \\
(\mathbf{0 . 0 0}) *\end{array}$ & $\begin{array}{l}-1.548 \\
(\mathbf{0 . 0 6}) * *\end{array}$ & $\begin{array}{l}-5.182 \\
(\mathbf{0 . 0 0})^{*}\end{array}$ & $\begin{array}{l}35.733 \\
(\mathbf{0 . 0 0}) *\end{array}$ & $\begin{array}{l}165.52 \\
(\mathbf{0 . 0 0}) *\end{array}$ & $\mathrm{I}(0)$ \\
\hline lBP & $\begin{array}{l}2.89340 \\
(\mathbf{0 . 9 9 8 )}\end{array}$ & $\begin{array}{l}3.2353 \\
(\mathbf{0 . 9 9 4 )}\end{array}$ & $\begin{array}{l}0.2449 \\
(\mathbf{0 . 9 9})\end{array}$ & $\begin{array}{l}0.1983 \\
(\mathbf{0 . 1 0})\end{array}$ & $\begin{array}{l}-0.570 \\
(\mathbf{0 . 2 8 4})\end{array}$ & $\begin{array}{l}0.4557 \\
(\mathbf{0 . 6 7 5 )}\end{array}$ & $\begin{array}{l}1.6548 \\
(\mathbf{0 . 8 0})\end{array}$ & $\begin{array}{l}1.6686 \\
(\mathbf{0 . 7 9 )}\end{array}$ & $\mathrm{I}(1)$ \\
\hline$D l B P$ & $\begin{array}{l}0.21985 \\
(\mathbf{0 . 5 8 7})\end{array}$ & $\begin{array}{l}-6.538 \\
(\mathbf{0 . 0 0}) *\end{array}$ & $\begin{array}{l}51.399 \\
(\mathbf{0 . 0 0}) *\end{array}$ & $\begin{array}{l}212.63 \\
(\mathbf{0 . 0 0}) *\end{array}$ & $\begin{array}{l}0.9336 \\
(\mathbf{0 . 8 2 4})\end{array}$ & $\begin{array}{l}-6.387 \\
(\mathbf{0 . 0 0})^{*}\end{array}$ & $\begin{array}{l}45.214 \\
(\mathbf{0 . 0 0}) *\end{array}$ & $\begin{array}{l}220.20 \\
(\mathbf{0 . 0 0}) *\end{array}$ & $\mathrm{I}(0)$ \\
\hline lBPR & $\begin{array}{l}0.5939 \\
(\mathbf{0 . 2 3 7 5 9 )}\end{array}$ & $\begin{array}{l}-0.323 \\
(\mathbf{0 . 3 7})\end{array}$ & $\begin{array}{l}3.5320 \\
(\mathbf{0 . 1 5})\end{array}$ & $\begin{array}{l}3.9437 \\
(\mathbf{0 . 4 1})\end{array}$ & $\begin{array}{l}-0.277 \\
(\mathbf{0 . 3 9 2})\end{array}$ & $\begin{array}{l}-2.52 \\
(\mathbf{0 . 0 1})^{*}\end{array}$ & $\begin{array}{l}12.343 \\
(\mathbf{0 . 0 2}) *\end{array}$ & $\begin{array}{l}13.478 \\
(\mathbf{0 . 0 0}) *\end{array}$ & $\mathrm{I}(1)$ \\
\hline$D l B P R$ & $\begin{array}{l}-6.2372 \\
(\mathbf{0 . 0 0}) *\end{array}$ & $\begin{array}{l}-10.08 \\
(\mathbf{0 . 0 0}) *\end{array}$ & $\begin{array}{l}95.812 \\
(\mathbf{0 . 0 0}) *\end{array}$ & $\begin{array}{l}187.88 \\
(\mathbf{0 . 0 0}) *\end{array}$ & $\begin{array}{l}-6.972 \\
(\mathbf{0 . 0 0})^{*}\end{array}$ & $\begin{array}{l}-10.01 \\
(\mathbf{0 . 0 0})^{*}\end{array}$ & $\begin{array}{l}86.387 \\
(\mathbf{0 . 0 0}) *\end{array}$ & $\begin{array}{l}183.96 \\
(\mathbf{0 . 0 0}) *\end{array}$ & $\mathrm{I}(0)$ \\
\hline lOIL & $\begin{array}{c}0.54725 \\
(\mathbf{0 . 7 0 8 )}\end{array}$ & $\begin{array}{l}0.4717 \\
(\mathbf{0 . 6 8 1 4})\end{array}$ & $\begin{array}{l}1.6255 \\
(\mathbf{0 . 8 0 )}\end{array}$ & $\begin{array}{l}1.6935 \\
(\mathbf{0 . 7 9})\end{array}$ & $\begin{array}{l}-0.090 \\
(\mathbf{0 . 4 6 )}\end{array}$ & $\begin{array}{l}-3.418 \\
(\mathbf{0 . 0 0 0 3})^{*}\end{array}$ & $\begin{array}{l}19.210 \\
(\mathbf{0 . 0 0}) *\end{array}$ & $\begin{array}{l}13.140 \\
(\mathbf{0 . 1 1})\end{array}$ & $\mathrm{I}(1)$ \\
\hline DlOIL & $\begin{array}{l}-8.1519 \\
(\mathbf{0 . 0 0}) *\end{array}$ & $\begin{array}{l}-8.848 \\
(\mathbf{0 . 0 0}) *\end{array}$ & $\begin{array}{l}79.5880 \\
(\mathbf{0 . 0 0}) *\end{array}$ & $\begin{array}{l}128.300 \\
(\mathbf{0 . 0 0})^{*}\end{array}$ & $\begin{array}{l}-9.493 \\
(\mathbf{0 . 0 0})^{*}\end{array}$ & $\begin{array}{l}-8.647 \\
(\mathbf{0 . 0 0}) *\end{array}$ & $\begin{array}{l}69.9487 \\
(\mathbf{0 . 0 0 0}) * \\
\end{array}$ & $\begin{array}{l}119.790 \\
(\mathbf{0 . 0 0 0}) *\end{array}$ & $\mathrm{I}(0)$ \\
\hline
\end{tabular}

Note. $D l F P=$ first difference of $\log$ of food prices, $D l I R=$ first difference of $\log$ of interest rates, $D l B P=$ first difference of $\log$ of bio-ethanol production, $D l B P R=$ first difference of log of ethanol prices, $D l O I L=$ first difference of $\log$ of oil prices. * refers to $5 \%$ significant level and $* * 10 \%$ significant level

\subsection{Cointegration Test Results}

Panel cointegration was carried out based on the Pedron test. The results from this are reported in Table 2. Pedron tests the null hypothesis of no cointegration against an alternative of cointegration. The results from the Pedron cointegration test suggest that only five tests of Pedron (Engle-Granger) reject the null hypothesis. The Panel p and pp statistic, Panel adf statistic, and the Group pp statistic reject the null hypothesis of no cointegration with 5\% significance level whilst the Group adf statistic reject the null at $10 \%$ level of significance. 
The Impact of Biofuels on Food Prices; The Experiences of Brazil and United States

Table 2: Pedron Cointegration Test Results

\begin{tabular}{|c|c|c|}
\hline Tests & Standardized Statistics & P-Values \\
\hline \multicolumn{3}{|c|}{ Pedron (Engler-Granger based) } \\
\hline Panel v statistic & $-1,128027$ & 0,8268 \\
\hline Panel p statistic & 0,307842 & $0,0491 * *$ \\
\hline Panel pp statistic & 0,471623 & $0,0494 * *$ \\
\hline Panel adf statistic & 0,343569 & $0,0397 * *$ \\
\hline Group p statistic & 0,337123 & 0,6234 \\
\hline Group pp statistic & 0,122386 & $0,0348 * *$ \\
\hline Group adf statistic & $-0,222396$ & $0,0921 *$ \\
\hline
\end{tabular}

Notes:

(1) Panel $v$ is non-parametric variance ratio statistic. Panel $p$ and panel pp are analogous to the non-parametric Phillips-Perron $p$ and $t$-statistic, respectively. Panel adf is a parametric statistic based on the augmented DickeyFuller ADF statistic. Group $p$ is analogous to the Phillips-Perron p statistic. Group pp and group adf are analogous to the Phillips-Perron t-statistic and the augmented Dickey-Fuller ADF statistic, respectively.

(2) The null hypothesis of no cointegration is tested. *, **, *** indicates the parameters that are significant at $10 \%$, $5 \%, 1 \%$ probability respectively.

(3) Null hypothesis: No cointegration

\subsection{Dynamic Ordinary Least Squares Output (DOLS)}

Having established the presence of cointegration, the next step was to estimate the long-run cointegrating vector. The study utilised the Dynamic Ordinary Least Square (DOLS) methodology. Table 3 below reports the results

Table 3: Dynamic Ordinary Least Square (DOLS) Results (1985-2013)

\begin{tabular}{cccrc}
\hline \hline Variable & Coefficient & Std. Error & t-Statistic & Prob. \\
\hline \hline LIR & -0.038297 & 0.020015 & -1.913440 & 0.0564 \\
LOIL & 0.420624 & 0.044221 & 9.511924 & 0.0000 \\
LBP & 0.219680 & 0.042935 & 5.116605 & 0.0000 \\
LBPr & 0.103288 & 0.069898 & 1.477693 & 0.1403 \\
DUMMY & 0.159057 & 0.045399 & 3.503557 & 0.0005 \\
\hline \hline R-squared & 0.844347 & & & \\
Adjusted R-squared & 0.830780 & & & \\
Observations & 450 & & & \\
\hline \hline
\end{tabular}

Notes:

(1) Dependent variable: Food Prices

(2) The DOLS was estimated including two lags and one lead

In the DOLS model output in Table 3, all explanatory variables (oil, biofuel production interest rates, biofuel prices, and dummy) fall in line with theoretical predictions. Interestingly four explanatory variables out of five are statistically significant but occurring at 0 and 10 percent level of significance.

The energy market, with crude oil as its proxy, is significant at 1 percent level as shown by the probability of 0.000 and is in line with economic theory. A t-value of 9.512, which is greater than 1.5 in absolute terms, also supports the significance of oil as a variable in explaining changes in food prices. A one hundred percent increase in the price of crude oil across time and between countries would result in an average increase in food prices by 42.1 percent. The intuition behind this is that energy market has a role to play in food price inflation in Brazil and U.S. This is consistent with The Sustainable Development Commission, which concluded an increase in a barrel of oil would cause food prices to increase ( USDA, 2008). 
Ncube et al. Adv. J Social Sci.; Vol. 2 Issue 1, pp: 12-22, May 2018

In addition, biofuel production proxied by ethanol production is one of the most important predictors of food prices since it is significant at a conventional level of 1 percent (probability of $0.000<0.05$ ). The $t-$ statistic of 5.117, which is greater than the critical value of 2 and the standard error of 0.04 cement that ethanol production is significant in explaining the changes in food prices. These results are consistent with the a priori expectations and corroborate the findings of (Mointeiro, Altman, \& Lahiri, 2012) in their study of Brazil. This suggests a one hundred percent increase in biofuel production across time and between countries will result in the increase of food prices by 22 percent. The study therefore rejects the null hypothesis that states, biofuel production does not have a statistically significant negative impact on food prices in U.S. and Brazil, and accept the alternative that biofuel production.

The results also show that food prices in Brazil and U.S. are influenced by interest rates since interest rates has a p-value that is significant at 90\% confidence interval. Furthermore, the results are consistent with economic theory which suggests that a rise in interest rates (IR) will result to a decrease in food prices and lowering of the real interest rate consequently raises food prices (Bastourre, Carrera, \& Ibarlucia, 2010). In addition to the concurrence of this relationship with theory the significant p value at $10 \%(0.0564)$, assumes a reinforcing relationship between the two economic variables.

However, despite being concurrent with economic theory, biofuel prices do not have a significant influence on food prices. The results show that the two-tailed $\mathrm{p}$ value null hypothesis of each coefficient being different from zero cannot be rejected, as the value of 0.1403 for biofuel prices is greater than the alpha of 0.10. Therefore, we fail to reject the null hypothesis and conclude that biofuel prices do not have a statistically significant negative impact on food prices in U.S. and Brazil. During drought times, ceteris paribus, food prices are higher by about $15.9 \%$. Drought significantly influences food prices as supported by the $\mathrm{p}$ value less than $1 \%$. Thus, the overall result implied by these is that food prices during drought times and food prices during non-drought times are statistically different from each other.

\subsection{Robustness of the Model}

The results also show that the data used in the study is robust. An $\mathrm{R}^{2}$ above 50 per cent is evidence to the robustness of this model (approximately 84.4 per cent in this study). The $\mathrm{R}^{2}$, which measures the closeness of fit in the regression model, advises that there is satisfaction in the statistical fitness of the model to the data. To discern the fitness of the model the actual versus fitted residuals can be presented in the form of a graph (Brooks, 2002). Figure 3 below depicts this graphical presentation. Although there is still a considerable, margin of error figure 3 shows that the model fits the data in a reasonable way. In other words, the test generally confirms the adequacy of the restricted error correction specification.

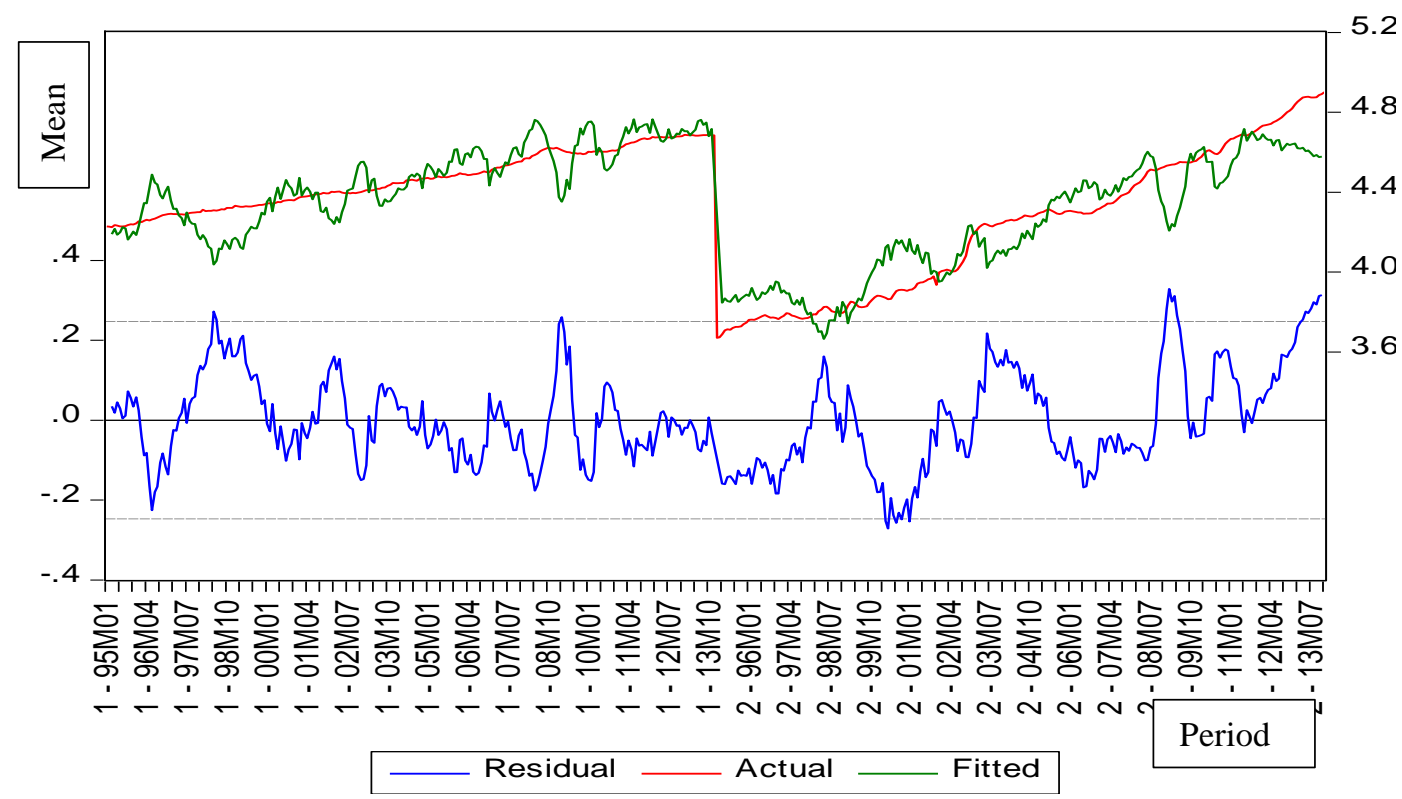

Figure 3: Residual against fitted values 


\subsection{Diagnostic Tests}

The Bera-Jarque (BJ) test is among the most commonly used tests for normality. It tests the null hypothesis of normality (symmetric) against an alternative on non-normal (skewed). The null hypothesis of normality would be rejected if the residuals from the model are either significantly skewed or leptokurtic/ platykurtic (or both). For the Histogram and Normality Test, Jarque-Bera is 15.1773 and the Probability is 0.147274 . Thus, the Jarque-Bera statistic is not significant at 5 percent significance level we fail to reject the null hypothesis and concluding the residuals are normally distributed, hence the histogram should be bellshaped.

\section{Conclusion}

The study significantly revealed that biofuel production causes the prices of food to increase once its production increases. It also revealed that oil and interest rates are some of the most cardinal predictors of food prices. These results were consistent with economic theories. However, biofuel prices, was insignificant in explaining the changes in food prices. The R squared support the robustness of the model. Diagnostic tests for normality further validated the parameter estimation outcomes achieved by the estimated model.

Since South Africa has placed a biofuel blending mandate as of October 1, 2015 as highlighted foretime, certain lessons can be drawn from the results of the study and the literature surrounding the experience of these two countries Brazil and U.S. Firstly, other countries including South Africa can learn the detriments of using the staple food for its biofuel production. U.S. experience shows that this would exacerbate increase in food prices. The increase in food prices would likely increase poverty as most of the poor have their diet made up of the staple food. Secondly, seeing that despite avoiding using the staple crop in the case of Brazil (sugarcane), any food crop would still cause the food versus fuel debate to illuminate, it is therefore worth pointing out that these developing countries invest more research and technology on second generation biofuels since the first generation have been evidenced to cause food prices to rise. The high biofuel mandates and subsidies have also motivated the production of food for large volumes of biofuels instead for consumption. Hence, all the other developing countries and South Africa need to be weary of high mandates that foster a supply shortfall. The target mandates should be manageable and flexible such that in times when yields are low, the target is adjusted downward.

\section{How to Cite this Article:}

Ncube F. P., Ndlovu K. T., \& Tsegaye A. (2018, January 1). The Impact of Biofuels on Food Prices; The Experiences of Brazil and United States. Advanced Journal of Social Science, 2(1), 12-22. doi: 10.21467/ajss.2.1.12-22

\section{References}

Alexander, C., \& Hurt, C. (2007). Biofuels and their impact on food prices. Purdue University, Department of Agricultural Econimics. Purdue Extension.

Amadeo, K. (2017, May 22). The Balance. Retrieved December 8, 2017, from Why are food prices rising? Causes of food price inflation: https://www.thebalance.com/why-are-food-prices-rising-causes-of-food-price-inflation-3306099

Balcombe, K., \& Rapsomanikis, G. (2008). Bayesian estimation and selection of nonlinear vector error correction model: The case of the sugar-ethanol-oil nexus in Brazil. American Journal of Agriculture Economics, 3(90), 658-668.

Bastourre, D., Carrera, J., \& Ibarlucia, J. (2010). Commodity Price: Structural Factors, Financial Markets and Non-Linear Dynamics. Argentina: BCRA.

Boddiger, D. (2007). Boosting biofuel crops could threaten food security. The Lancet, 370(9591), 923-24.

Brooks, C. (2002). Introductory Econometrics for Finance”. Cambridge University.

Clark, G. (2003, August 17). mdgs in plain language: No more broken promises. Retrieved June 25, 2014, from Seafield Research and Development Services: http://www.srds.co.uk/

Fortenbery, T. R., \& Park, H. (2008). The Effect of Ethanol Production on the U.S. National Corn Price. Staff Report, University of WisconsinMadison, Department of Agricultural \& Applied Economics, United States.

Hamilton, J. (2009). Causes and Consequences of the Oil Shock of 2007-08. Brooking Papers on Economic Activity, $215-283$.

Liu, D. (2005). Chinese development status of bioethanol and biodisiel. Tsinguhua University . Beijing: Biofuels: An energy solution.

Mointeiro, N., Altman, I., \& Lahiri, S. (2012). The Impact of ethanol production of food. . Energy Policy, 41, 193-200.

Pettinger, T. (2011, October 19). Cost push inflation. Retrieved September 26, 2014, from Economics help: http://www.economicshelp.org 
Qui, C., Colson, G., Escalante, C., \& Wetzstein, M. (2012). Considering macroeconomic indicators in the food versus fuel nexus. Energy Economics, 2021-2028.

Rice, T. (2009). Meals per gallon: the impact of industrial biofuels on people and global hunger. Actionaid.

Serra , T., Zilberman, D., \& Gil, J. (2011). Price Volatility in Ethanol Markets. European Review of Agricultural Economics, 2(38), 59-80.

Sharma, A. (2008). Is Higher Demand for Biofuels Fuelling Food Prices? Economic and Political Weekly Stable, 43(32), 37-40.

Sihvonen, J. (2017). Biofuels policies do increase food prices. Transport and Environment. Retrieved from https://www.transportenvironment.org/sites/te/files/publications/Food\%20price\%20Briefing\%202017.pdf

Stauffer, C., \& Cascione, S. (2013). Brazil's food inflation: don't blame it all on the weather. Brazil: Reuters.

Teweldemedhin, M. Y., \& Mwewa, L. (2013). Bio fuel production and its implication on food security: Case study from Zambia. African Journal of Agricultural Research, 9(5), 577-587.

U.S Department of Energy. (1999). Renewable Energy: Biofuels. Retrieved June 19, 2014, from U.S. Department of Energy: htt:p//www.nrel.gov

USDA. (2008). Grain: World Markets and Trade. Foreign Agricultural Services. Washington DC.

Publish your research article in AIJR journals-

$\checkmark$ Online Submission and Tracking

$\checkmark$ Peer Reviewed

$\checkmark$ Rapid decision

$\checkmark$ Immediate Publication after acceptance

$\checkmark$ Open Access (Articles freely available online)

$\checkmark$ Retain full copyright of your article.

Submit your article at journals.aijr.in 